\title{
https://doi.org/10.48009/2_iis_2006_182-186 \\ E-BUSINESS ADOPTION: FROM THE ECONOMIC AND STRATEGIC MANAGEMENT PERSPECTIVES
}

\author{
Fujun Lai, University of Southern Mississippi, fujun.lai@usm.edu \\ Weihua Shi, University of Southern Mississippi, weihua.shi@usm.edu \\ Jian Wang, University of International Business and Economics (China), wangjian@ibb.cn \\ Joe Hutchinson, University of Southern Mississippi, Joe.Hutchinson@usm.edu
}

\begin{abstract}
This study proposed a model to investigate e-business adoption from the economic and strategic management perspectives by incorporating network externalities and strategic information orientation. The model was tested using survey data from 307 international trading companies in China. The results indicated that both network externalities and information orientation were important e-business adoption enablers. The influences of these two factors on e-business adoption were partially mediated by the firm's expected benefits from $e$ business adoption.
\end{abstract}

Keywords: E-business Adoption, Network Externalities, Information Orientation

\section{INTRODUCTION}

E-business adoption is a complex and important decision faced by a company because it requires business process changes and significant financial investments [23]. Various factors influencing ebusiness adoption have been identified and investigated in previous studies, using the technology-organization-environment framework, institutional theory, and diffusion of innovation theory (e.g. [3, 22, 25]). The present study investigated e-business adoption from the economic and strategic management perspectives. Specifically, network externalities and information orientation were proposed to influence e-business adoption. Few studies have examined e-business adoption from these perspectives [24].
Network externalities, or network effects, refer to user benefits being associated with the size of the network [13, 14]. The concept of network externalities has been used in a number of analytical models to improve the understanding of e-business adoption (e.g. [1, 2, 18]). However, there has been limited empirical testing of these models [15, 23].

Information orientation refers to a company's deeply rooted set of values and beliefs regarding information activities [7]. As an important measurement of a firm's capability, information orientation defines the resources to transcend individual capabilities and unify the resources and capabilities into a cohesive whole [6]. Therefore, information orientation may have fundamental influences on e-business adoption. However, few studies have examined the influences of information orientation on e-business adoption.

The objective of the present study was to investigate the impact of network externalities and information orientation on e-business adoption. We proposed that network externalities and information orientation influence e-business adoption directly and indirectly.

\section{CONCEPTUAL MODEL AND HYPOTHESES}

The conceptual model is presented in Figure 1. In the model, network externalities and information orientation were proposed to positively influence ebusiness adoption. Meanwhile, we also incorporated expected benefits to mediate the influences of network externalities and information orientation on e-business adoption. The control variables of ownership, industry type, size, and age also were proposed to influence e-business adoption. 


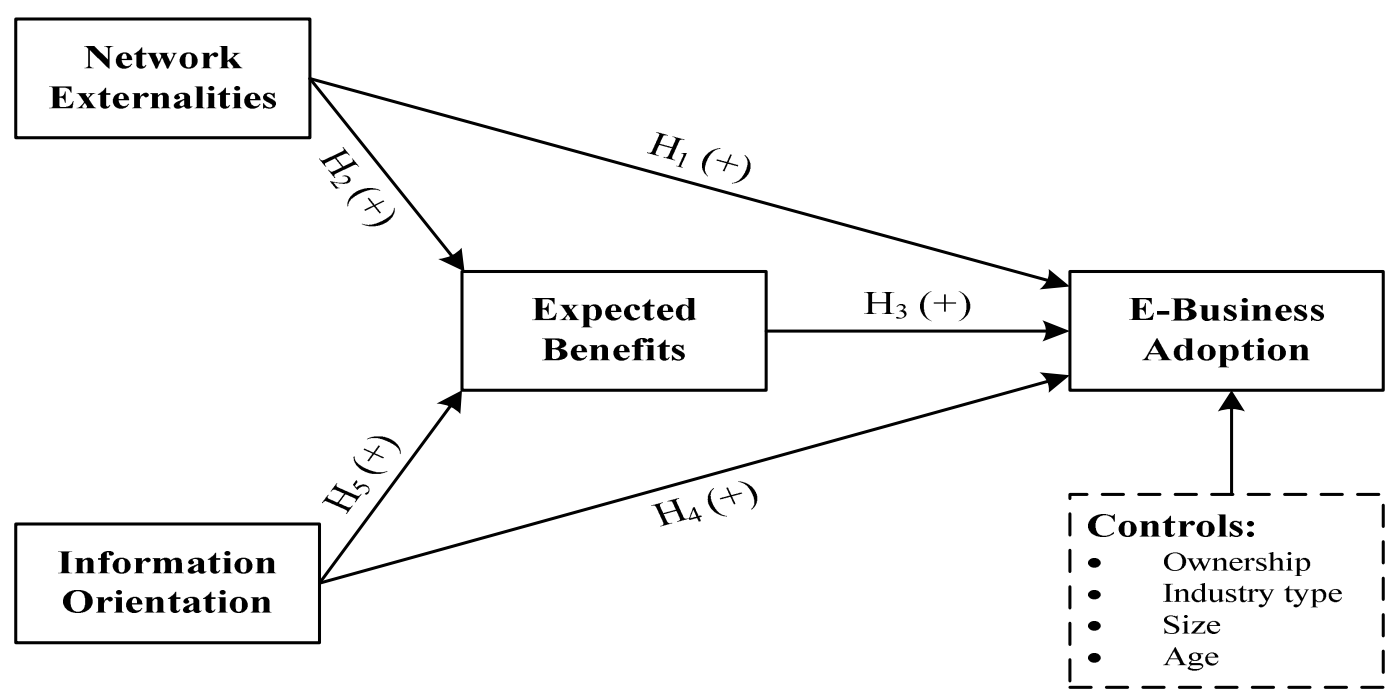

Figure 1: Conceptual Model

\section{Network Externalities}

Network externalities enhance the value of e-business as the size of the e-business network increases. Thus, there is an incentive for companies to adopt ebusiness as more companies adopt e-business. Network externalities may influence e-business adoption in two ways. First, the participation of vertical partners in the supply chain, such as suppliers and customers, may require companies to adopt ebusiness in order to build compatible interorganizational systems. Second, e-business diffusion among horizontal peers also may motivate companies to adopt e-business [22]. As more peers adopt ebusiness, a larger market for complementary goods, such as hardware, software, and e-business related professional services (e.g., payment, logistics, and network security) will emerge. This will accelerate ebusiness adoption, as the larger market may result in intensified competition and force product and service price reductions. Therefore, we expect that network externalities have significant influences on e-business adoption.

\section{$H_{1}$ : Network externalities significantly} accelerate e-business adoption

\section{Expected Benefits}

Expected benefits refer to the operational benefits a firm expects from e-business adoption. The potential benefits may include cost reduction, productivity improvement, and market expansion [16, 23]. By using Internet-based technologies, firms are able to reduce information asymmetry, facilitate expansion into new markets, and reach new customers.
The expected benefits derived from value chain coordination, market expansion, and cost reductions should increase as network externalities increase [17, 24]. Zhu et al. [24] found that higher network externalities resulted in higher expected benefits in the context of open-standard inter-organizational system adoption. Therefore, we hypothesize:

$\mathrm{H}_{2}$ : Network externalities positively influence a firm's expected benefits from e-business adoption

A firm's benefit expectation may be an important decision factor for e-business adoption. Innovation diffusion theory suggests that perceived benefits are an important driver of new technology adoption [19]. Therefore, we hypothesize:

$$
\begin{aligned}
& H_{3}: \text { A firm's expected benefits from e-business } \\
& \text { adoption positively influences e-business } \\
& \text { adoption }
\end{aligned}
$$

\section{Information Orientation}

The values and beliefs represented by information orientation can offer guidance to managers about the opportunities and risks in e-business adoption. In addition, the values and beliefs can legitimize the willingness of managers to commit their efforts to ebusiness [3]. Meanwhile, a stronger information orientation may facilitate information acquisition and dissemination, promote the development of new knowledge [9], and increase the diversity of knowledge [20], improving an organization's ability to innovate [5]. This will help the firm to recognize 
new opportunities, which will spur the firm to develop new strategic initiatives for innovation, such as e-business adoption. Together, this suggests that:

\section{$H_{4}:$ Information orientation positively relates to e-business adoption}

Stronger information orientation means that a firm highly values information-related strategies and has higher expectations in terms of information's various benefits. Since companies with higher information orientation may have obtained better information infrastructure and implemented more flexible organizational structures, they also may expect higher returns. This leads to:

\section{$\mathrm{H}_{5}$ : Information orientation positively relates to expected benefits}

\section{Controls}

Contextual characteristics could influence e-business adoption. The widely cited contextual factors are firm size, firm age, ownership, and industry type [3]. We included these factors in our research model as control variables.

\section{METHODOLOGY}

Measurement items were developed based on a comprehensive review of the literature. The development of our measurement items followed the three successive stages of theoretical specification, statistical testing, and refinement [21]. The measures of network externalities were adapted from $\mathrm{Zhu}$ et al. [24]. The measures for information orientation were developed by combining expert opinions and adaptations from previous studies [11, 12]. Expected benefits were measured in terms of cost reductions, productivity improvements, better communication, improved personnel management [16, 23], and new business opportunities [3]. E-business adoption was measured as the extent to which e-business was diffused into routine business activities and processes [3]. Firm size and age were measured using the number of employees in the firm and the number of years the company had operated in China, respectively $[22,25]$. The measures of ownership and industry type were also adapted from previous studies [3].

Our sample was selected from a database of 2,075 Chinese international trading companies published by the Beijing Municipal Bureau of Commerce. To help respondents better understand the questionnaire instrument and to improve the survey response rate, we collected our data by personally-administered interview surveys rather than mail surveys. We first phoned all of the 2,075 registered trading companies. After 812 companies agreed to participate in the survey, follow-up phone calls were made to schedule interview appointments with IT managers or operations managers of 500 companies randomly selected from those 812 companies. Appointments with 54 of the 500 selected companies could not be arranged, so formal interviews were conducted with senior IT managers or operations managers from the remaining 446 companies. A total of 307 interviews were successfully completed, representing a $14.8 \%$ response rate.

\section{ANALYSES AND RESULTS}

PLS-Graph 3.00, a Partial Least Squares (PLS) tool, was used in this study to assess the measurement model and structural model. PLS is a powerful SEM technique that has been used extensively in information system research [8]. PLS was used in this study because our model had formative constructs, which could not be handled by other SEM methods. In addition, PLS does not place a high requirement on sample size or normal distribution of source data $[4,8]$.

After considering the relationships of the measurement items and their respective constructs, we specified all first-order constructs as formative constructs [4]. We used a bootstrapping estimation procedure to assess the significance of the factor weights of the scales in the measurement model and the path coefficients in the structural model [8]. The results showed that all measurement items had significant $\quad(p<0.001)$ weights and acceptable magnitudes [4], suggesting acceptable measures of reliability and validity.

The structural model was assessed by estimating the path loadings and the $\mathrm{R}^{2}$ values. Path loadings indicate the strengths of the relationships between the independent variables and dependent variable. Interpreted like multiple regression results, $\mathrm{R}^{2}$ values indicate the amount of variance explained by the exogenous variables and measure the predictive power of the structural models. The results of our hypotheses testing are presented in Figure 2.

As indicated by path loadings, network externalities had significant influences on e-business adoption and expected benefits $(b=0.274$ and 0.427 , respectively; $p<0.001)$. This result confirmed our theoretical expectation and provided support for $\mathrm{H}_{1}$ and $\mathrm{H}_{2}$. The significant loadings from expected benefits to e- 
business adoption $(b=0.320, p<0.001)$ provided support for $\mathrm{H}_{3}$.

The path from information orientation to e-business adoption was highly significant $(b=0.195, p<0.001)$, indicating information orientation facilitates e- business adoption. This provided support for $\mathrm{H}_{4}$. The path from information orientation to expected benefits also was significant and of high magnitude ( $b=0.597, p<0.001)$, suggesting support for $\mathrm{H}_{5}$.

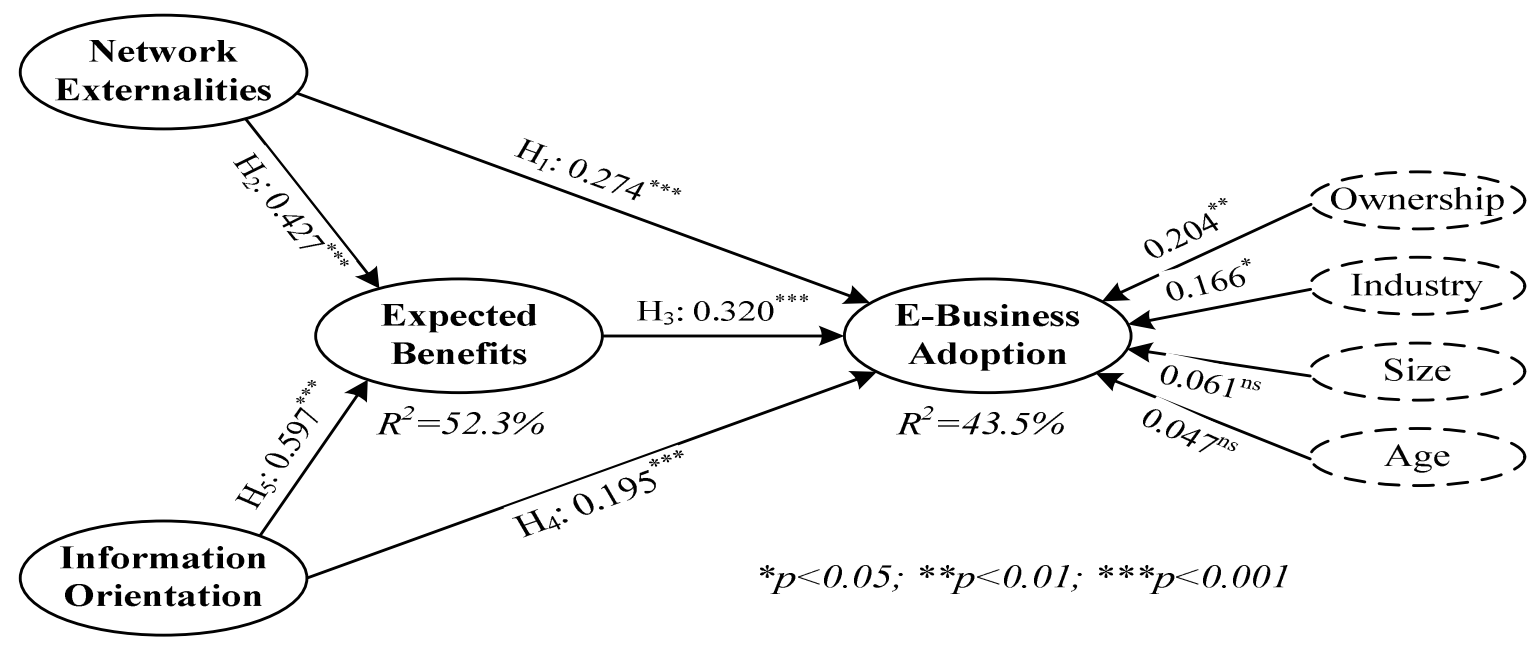

Figure 2: Results of Hypotheses Testing of the Structural Model

Regarding controls, ownership and industry had significant influences on e-business adoption $(b=$ $0.204, p<0.01$ and $b=0.166, p<0.05$, respectively). The influences of company and company age were not significant.

As shown in Figure 2, our model explained 52.3\% of the variance in expected benefits and $43.5 \%$ in ebusiness adoption.

\section{DISCUSSION}

The support for $\mathrm{H}_{1}$ indicated that e-business adoption was influenced by network externalities. This implies that companies are more likely to benefit from ebusiness adoption when their peer and partner companies support e-business. Thus, companies are more likely to adopt e-business when greater network externalities exist. This finding was consistent with several previous studies. For example, Granovetter [10] suggested that decisions to engage in a particular behavior depended on the perceived number of similar others in the environment, especially resource-dominant organizations that had done likewise. Teo et al. [22] found that the greater the interorganizational technology adoption among competitors, suppliers, and customers, the greater the likelihood that organizations would adopt this technology.

The mediation effect of expected benefits was manifested by the large path loadings from network externalities and information orientation to expected benefits and the significant path loading from expected benefits to e-business adoption. However, it is interesting to note that the direct effects from network externalities and information orientation were still significant. This implies that network externalities and information orientation influence ebusiness adoption for reasons other than expected benefits [25].

\section{CONCLUSION}

Drawing on economic perspectives of network externalities and strategy management perspectives of information orientation, this study proposed a conceptual model to examine two e-business adoption enablers. The model was tested using the dataset from our personally-administered interview survey. The results gauged the significant roles of network externalities and information orientation on e-business adoption. The effects of network externalities and information orientation on ebusiness adoption may partially contribute to the 
expectation of benefits from e-business adoption, such as cost reductions, market expansion, and supply chain coordination.

\section{REFERENCES}

1. Asvanund, A., Clay, K., Krishnan, R. \& Smith, M.D (2004). An Empirical Analysis of Network Externalities in Peer-to-Peer Music-Sharing Networks. Information Systems Research, 15(2), 155-174

2. Bhargava, H.K. \& Choudhary, V. (2004). Economics of an Information Intermediary with Aggregation Benefits. Information Systems Research, 15(1), 22-36

3. Chatterjee, D., Grewal, R. \& Sambamurthy, V. (2002). Shaping Up for E-Commerce: Institutional Enablers of the Organizational Assimilation of Web Technologies. MIS Quarterly, 26(2), 65-89

4. Chin, W.W. (1998). Issues and Opinion on Structure Equation Modeling. MIS Quarterly, 22(1), vii - xvi.

5. Cohen, W.M. \& Levinthal, D.A. (1990). Absorptive capacity: A new perspective on learning and innovation. Administrative Science Quarterly, 35(1), 128-152

6. Day, G.S. (1994). The Capabilities of MarketDriven Organizations. Journal of Marketing, 58(4), 37-52.

7. Gatignon, H. \& Xuereb, J. (1997). Strategic Orientation of the Firm and New Product Performance. Journal of Marketing Research, 34(1), 77-90.

8. Gefen, D. \& Straub, D. (2005). A Practical Guide to Factorial Validity Using PLS-Graph: Tutorial and Annotated Example. Communications of the Association for Information Systems, 16, 91-109

9. Ghoshal, S. \& Moran, P. (1996).Bad for practice: A critique of the transaction cost theory. Academy of Management Review, 21(1), 13-47

10. Granovetter, M. (1978). Threshold Models of Collective Behavior. American Journal of Sociology, 83(6), 1420-1443

11. Hult, G.T.M., Ketchen, D.J.J. \& Slater, S.F. (2004). Information Processing, Knowledge Development, and Strategic Supply Chain Performance. Academy of Management Journal, 47(2), 241-253

12. Jayachandran, S., Sharma, S., Kaufman, P. \& Raman, P. (2005). The Role of Relational Information Processes and Technology Use in
Customer Relationship Management. Journal of Marketing, 69(4), 177-192

13. Katz, M. \& Shapiro, C. (1986). Technology Adoption in the Presence of Network Externalities. Journal of Political Economics, 94(4), 822-841

14. Kauffman, R.J. \& Wang, Y.M. (2002). The Network Externalities Hypothesis and Competitive Network Growth. Journal of Organizational Computing and Electronic Commerce, 12(1), 59-83

15. Kauffman, R.J., McAndrews, J., \& Wang, Y.M. (2000). Opening the 'Black Box' of Network Externalities in Network Adoption. Information Systems Research, 11(1), 61-82.

16. MacKay, N., Oarent, M. \& Gemino, A. (2004). A Model of Electronic Commerce Adoption by Small Voluntary Organizations. European Journal of Information Systems, 13(2), 147-159

17. Mukhopadhyay, T., \& Kekre, S (2002). Strategic and Operational Benefits of Electronic Integration in B2B Procurement Processes," Management Science, 48(10), 1301-1313.

18. Riggins, F.J., Kriebel, C.H., \& Mukhopadhyay, T. (1994). The Growth of Interorganizational Systems in the Presence of Network Externalities. Management Science, 40(8), 984998

19. Slater, S.F. \& Narver, J.C. (1995). Market orientation and the learning organization. Journal of Marketing, 59(3), 63-74

20. Rogers, E.M. (1995). Diffusion of Innovations, NY: Free Press

21. Straub, D. (1989). Validating Instruments in MIS Research. MIS Quarterly, 13(2), 147-169

22. Teo, H.H., Wei, K.K., \& Benbasat, I. (2003). Predicting Intention to Adopt Interorganizational Linkages: An Institutional Perspective. MIS Quarterly, 27(1), 19-49

23. Wang, S. \& Cheung, W. (2004). E-Business Adoption by Travel Agencies: Prime Candidates for Mobile e-Business. International Journal of Electronic Commerce, 8(3), 43-63

24. Zhu, K. Kraemer, K.L., Gurbaxani, V. \& Xu, S. (2006). Migration to Open-Standard Interorganizational Systems: Network Effects, Switching Costs, and Path Dependency. MIS Quarterly, forthcoming

25. Zhu, K., Kraemer, K., \& Xu, S. (2003). Electronic business adoption by European companies: a cross-country assessment of the facilitators and inhibitors. European Journal of Information System, 12(4), 251-268. 